\title{
Are Financial Distress and Firm Characteristics Restrict The Operating Segment Disclosure in Marine Industry?
}

\author{
Sri Ruwanti ${ }^{1 *}$ and Prima Aprilyani Rambe ${ }^{2}$ \\ ${ }^{1,2}$ Universitas Maritim Raja Ali Haji, Tanjungpinang, Indonesia
}

\begin{abstract}
This study aims to examine the effect of financial distress and several factors on company characteristics, firm size, audit quality and public ownership at the level of disclosure of operating segments in marine companies listed on the Indonesia Stock Exchange. 24 populations were observed from 2013 to 2017 and obtained a sample of 10 marine sector companies with purposive sampling method. Observation results obtained an average operating segment disclosure rate of 69\%. We found companies with financial difficulties limiting disclosure of operating segments. We also find public ownership influencing the level of disclosure of operating segments. However, it failed to prove the effect of firm size and auditor quality on the operating segment disclosure level.
\end{abstract}

Keywords: Big-4 Audit Firm, Financial Distress, Firm Size, Operating Segment, Public Ownership

\section{Introduction}

Indonesia has a vision to be the maritime axis of the world so that it is proper for the maritime industry to be able to boost the country's economy. Business developments in the maritime sector experienced a development as indicated by the presence of marine companies listed on the Indonesia Stock Exchange (IDX) to sell their shares in order to obtain capital from investors. Capital Market Chief Executive of OJK, Nurhaida said, "to develop an industry is inseparable from capital adequacy. To anticipate the need for capital, the maritime and fisheries sector industry needs to be encouraged to seek capital market funding through an initial public offering or IPO scheme.

Earnings information becomes an attraction for investors to invest capital. Research on marine companies listed on the Indonesia Stock Exchange was conducted by Arifin, Ruwanti and Kusasi (2016) showing the results that simultaneously profitability, liquidity and leverage affect earnings quality. In other studies investigating the top 130 shipping companies' shows that asset liquidity has a negative influence with leverage which implies a conflict of interest between managers and investors (Yeo, 2016)

Marine sector has various types of business such as sea transportation services, shipping services, port services, loading and unloading services, processing of seafood products and etcetera. The goods or services produced are sometimes produced and distributed in various places with different geographical areas. Diversification of products or services is carried out by the company to respond to the potential that exists and the needs of the community to bring profits to the company. With this diversification, the company's operations become diverse. Each operating activity is expected to be able to generate profits for the company.

There are problems that arise in the implementation of operating segment disclosures such as the results of Salendrez's research (2014) which motivated this study that none of the companies listed on the Philippine Stock Exchange fulfilled all disclosures of operating segments required in IFRS 8. While the research of Muhammad and Siregar (2014) shows that 65\% of segment disclosures are carried out

* Corresponding author. Email address : $\underline{\text { sriruwanti@umrah.ac.id }}$ 
by manufacturing companies listed on the IDX based on PSAK 5, companies that disclose more operating segments are large companies, audited by big four accountants and large institutional ownership. Many companies are reluctant to disclose segment information because of strategic and competitive hazards such as disclosing company strategy, level of overseas operations and internal integration to competitors that may be related to its disclosure (Odia \& Imagbe, 2015).

In reality the application of PSAK which is the adoption of IFRS is not easy to implement. Differences in interests between stakeholders can be related to the problems of each PSAK (Efferin and Rudiwarni 2014). Sometimes managers do not provide sufficient information to the owner about the condition of the company that affects investment decision making. This can lead to information asymmetry, namely the occurrence of information gaps between managers and owners because managers have more information than owners.

Financial statements should be a bridge between managers and stakeholders to inform the company's financial condition. In a financial condition that is not good even though information must be clearly conveyed. Webb and Cohen (2007) found that companies would improve the quality of disclosure in years where financial distress was indicated.

From this background, the question arises, whether the reporting of operating segments has achieved its objectives and how compliance with operating segment reporting by marine companies in Indonesia. The purpose of this study was to identifying the extent of disclosure of operating segments of marine companies listed on the Indonesia Stock Exchange. In addition, we also want to examine the effect of financial distress, company size, auditor quality, public ownership and the level of disclosure of operating segments

\section{Theoretical Background and Hypothesis Development Agency theory}

Jensen and Meckling (1976) define agent relations as contracts where one or more people (agents) involve another person (agent) to do some services on their behalf then delegate some decision making to the agent. If both parties maximize utility, then the agent may not always act in the interests of the principle. Because of several differences in interests between actors and agents, agency conflicts arise. To reduce differences in interests, the principal will arrange the right incentives for the agent and also issue monitoring costs so that the agent does not deviate.

Principal controlling the activities of the company through financial statements that are presented by agents who run the company's business activities. Agents provide information through the disclosures presented in the financial statements, both compulsory and voluntary. The agent in the company is the manager who is authorized to manage the company. The manager who is opportunistic will limit information to the principal so that disclosure becomes less qualified. Jiao (2011) found that the higher the disclosure rating will increase the growth of net income in the future.

Hermalin and Weisbach (2012) argue that disclosure can be a double-edged sword. On the one hand, through disclosure shareholders can monitor their managers, but the benefits of increasing the information do not flow completely to shareholders. On the other hand managers will capture greater compensation if they have bargaining power. Berger and Hann (2007) test at the segment level whether the manager's disclosure decisions are influenced by their ownership costs or their agency to hide segment profits. The results show that managers tend to hold segments with relatively high abnormal earnings if the ownership cost motive dominates, whereas managers tend to hold segments with abnormal returns that are relatively low if the agency costs dominate.

\section{Operating segment}

The accounting standard contains what accounting principles, methods and policies can be used by financial report makers. It is a guide to presenting financial 
statements in providing financial information of business entities to stakeholders. With the standards being enforced it is expected that the comparability between companies will be higher. The purpose of financial statements according to PSAK 1 Presentation of Financial Statements (IAI, 2015) provides information about financial position, financial performance, and cash flow of the entity that is beneficial for most users of financial statements in making economic decisions. This includes information about the entity's resources and claims on those resources, and the impact of transactions and other events and conditions that change those resources and claims. Users evaluate financial statements to make decisions such as whether or not to make additional investments to the entity, provide credit and financing, or assess management's efficiency and effectiveness in the use of entity resources (Harrison Jr et al, 2017). The International Accounting Standards Board (IASB) develops a set of high-quality International Financial Reporting Standards (IFRS) that can be understood, implemented and accepted globally. This is now used for public reporting purposes in more than 100 countries (Salendrez, 2014).

Standards related to operating segments are regulated in PSAK 5 (2014) which are fully adopted from IFRS 8 Operating Segments replacing PSAK (2000). According to PSAK 5 (2014) the operating segment is a component of the entity:

a. Those involved in business activities which earn income and incur expenses (including income and expenses related to transactions with other components of the same entity).

b. Its operating results are regularly reviewed by the operational decision maker to make decisions about the resources allocated to the segment and assess its performance.

c. Availability of financial information that can be separated.

The presentation of operating segments is reported if it meets the quantitative threshold. Quantitative thresholds include (1) income from a segment including sales to external customers is $10 \%$ or more of a combination of internal and external income, (2) the absolute amount of reported profit and loss from a segment is 10\% or more of the combined reported profit throughout operating segments that do not report losses with combined reported losses from all operating segments that report losses; (3) have assets of $10 \%$ or more of the combined assets of all operating segments.

\section{Hipotesis Development}

Effect of financial distress on the level of disclosure of operating segments

Segment performance in a company is important to observe. The operating segment also determines the success of the company to achieve profit objectives. If a segment cannot show good performance it can affect the overall performance of the company, especially if the segment that is performing poorly is the company's main operation. Good corporate governance will reduce the possibility of financial pressure, for example by commissioners who carry out their functions. The more number of commissioners, the lower the likelihood that companies will experience financial difficulties (Wardhani, 2007), while Juniarti (2013) studies cannot prove that good corporate governance can predict the company's financial difficulties. Wijantini (2006) found companies that experience financial difficulties tend to make more disclosures. Webb and Cohen (2007) find that companies will improve the quality of disclosure in years where financial distress is indicated.

From the explanation above, the following hypothesis is formed:

H1: Financial distress has a significant effect on the level of disclosure of operating segments

\section{Effect of company size on the level of disclosure of operating segments}

Agency theory shows the relationship between principal and agent where the principal is the owner and agent is the management that runs the company. Supervision 
by the owner of management raises agency costs. Large companies have higher agency costs so as to reduce agency cost disclosures become more widespread.

Large companies are more compliant with segment disclosure requirements than smaller companies (Sucuahi, 2013). In segment information research conducted by Schvirck, Lunkes and Gasparetto (2013) found that large companies will provide more segment information. The same results were also shown by Muhammad and Siregar (2014) and Ibrahim (2015) the size of the company has a positive effect on the extent of segment information disclosure. Alfraih and Alanezi (2011), Alfraih and Alshammari (2016) consistently show that firm size affects the disclosure of operating segments. Large companies tend to provide higher segment information quality (Fakhfakh, Shabou and Pige, 2018). From the explanation above, the following hypothesis is formed:

$\mathrm{H} 2$ : Company size has a significant effect on the level of disclosure of the operating segment

\section{Effect of quality of auditors on Operating Segments}

Audit firm which affiliated with Big-4 audit firm usually have a better reputation. This is because they have higher standards of recruitment and more and varied experiences. The quality of auditors is determined by whether or not they are members of the big-4 audit firm. Companies audited by big-4 audit firm tend to provide more disclosures. Alfraih and Alanezi (2011) and Alanezi's research, Alfraih Alshammari (2016) found that companies audited by big-4 audit firm revealed more segment information, as well as research results from Fakfah, Shabou, Pige (2018), Ibrahim (2015) and Muhammad and Siregar (2014) found the same results. disclosure

H3: Quality of auditor has significant effect on the level of operating segment

\section{Effect of public ownership on operating segments}

Agency conflict arises when there are differences in interests between the principal and agent. When the portion of public ownership is high over an entity, a large agency fee is also needed to overcome the agency conflict problem. One way that can be done to reduce the costs of a large agency is to make more disclosures. In an effort to increase the utility, managers can process financial information. The action taken is to set the profit as desired. One part that is regulated is segment information. Geographic diversification has a positive effect on earnings management and the relationship between geographical diversification and earnings management can be weakened by the presence of good corporate governance (Kusumayani \& Wirama, 2016), the results of Utami and Siregar (2016) also found that segment disclosures have a significant impact on management decline profit. The relationship between earnings quality and segment disclosure will weaken if the earnings quality is low (Blanco, Lara, \& Tribo, 2014). Muhammad and Siregar (2014) found the effect of public ownership on the extent of disclosure of operating segments, while Alanezi and Alfraih (2011), Alfraih and Alshammaril (2016) found that share ownership did not affect the extent of segment disclosures.

H4: Public Ownership has a significant effect on the level of disclosure of operating segments

\section{Research Methodology \\ Population, sample and data}

The population in this study are marine companies listed on the Indonesia Stock Exchange 2013-2017 which is engaged in fisheries, marine transportation, mining that 


\section{Are Financial Distress and Firm Characteristics Restrict The Operating Segment Disclosure in Marine Industry?}

has offshore activities. Samples were taken using purposive sampling with the following criteria:

1. Marine companies listed on the Indonesia Stock Exchange consecutively in the 2013-2017 observation periods.

2. The company has and publishes audited financial statements and ends December 31 in the 2013 to 2017 observation periods.

3. Using the rupiah currency during the 2013-2017 observation periods.

The data used in this study are annual financial reports obtained from the Indonesia Stock Exchange or IDX website and the websites of the companies that are sampled.

\section{Research model}

The purpose of this study was to determine the effect of financial distress, firm size, auditor quality and public ownership on the level of disclosure of operating segments. To test the hypotheses proposed, the research regression model is as follows:

Where:

$$
\text { SEGDISCL }=\beta_{0}+\beta_{1} \text { FDISS }+\beta_{2} \text { LNSIZE }+\beta_{3} \text { AUD }+\beta_{4} \text { DIFF }+\varepsilon
$$

SEGDISCL = Level of Operating segment disclosure

FDISS $\quad=$ Financial Distress

LNSIZE $\quad=$ Firm Size

AUD $\quad=$ Auditor Quality

DIFF $\quad=$ Public Ownership

$\beta_{0} \quad=$ intercept

$\beta_{1} \ldots \beta_{4} \quad=$ coefficient

$\varepsilon \quad=$ error

\section{Variables and measurement}

The variables used in this study consist of dependent variables and independent variables. The dependent variable is the level of disclosure of the operating segment and the independent variable is financial distress, firm size, auditor quality and public ownership.

\section{Dependent Variables \\ Level of Segment disclosure}

Segment disclosure level is measured by the index used by Alfraih and Alanezi (2011) which refers to International Accounting Standards (IAS) No.14. Dichotomy 1 if disclosed, 0 if not disclosed and $\mathrm{N} / \mathrm{A}$ if not applied. Index equals the amount disclosed divided by total disclosure.

\section{Independent variables}

Financial Distress

Financial distress is proxy using the Altman Z-Score with the following equation

Where:

$$
\mathrm{Z}=0.012 . \mathrm{X} 1+0.014 . \mathrm{X} 2+0.033 . \mathrm{X} 3+0.006 . \mathrm{X} 4+0.999 . \mathrm{X} 5
$$

$\mathrm{X} 1$ = working capital/total assets

$\mathrm{X} 2$ = retained earnings/total assets

$\mathrm{X} 3$ = earnings before interest and taxes/total assets

$\mathrm{X} 4=$ market value equity/book value of total liabilities

$\mathrm{X} 5$ = sales/total assets

$\mathrm{Z}=$ Overal index

\section{Firm Size}

The company size variable is measured using the natural logarithm of total assets referring to the measurements used by Alanezi, Alfraih and Alshammari (2016) and Muhammad and Siregar (2014). 


\section{Audit Quality}

Audit quality is measured using a dummy variable, that is 1 for companies audited by Big- 4 audit firm, and 0 for others refers to measurements used by Alanezi, Alfraih and Alshammari (2016) and Muhammad and Siregar (2014).

\section{Public Ownership}

Public ownership is the percentage of public share ownership of the number of shares outstanding referring to the measurement used refers to the measurements used by Alanezi and Alfraih (2011) and Muhammad and Siregar (2014).

\section{Results \\ Descriptive statistics}

This study took a sample of marine sector companies listed on the Indonesia Stock Exchange 2013-2017. Samples taken were marine companies listed on the Indonesia Stock Exchange in 2013-2017, published their financial statements from 2013-2017, using Rupiah and had data complete for use in this study. Of the 24 populations obtained 10 company samples and 50 observations. Sample identification is shown in the following table:

Table 1 Sample Identification

\begin{tabular}{lc}
\hline \multicolumn{1}{c}{ Identification } & Frequency \\
\hline Total marine companies during 2017 & 24 \\
Companies that have just listed during the 2013-2017 observation period & $(1)$ \\
Companies that do not publish financial statements during the 2013-2017 research period & $(2)$ \\
Companies that use currencies other than Rupiah in the 2013-2017 observation period & $(11)$ \\
Number of research samples per study period & $\mathbf{1 0}$ \\
Number of observations 10 x 5 years of study period & $\mathbf{5 0}$ \\
\hline
\end{tabular}

The average level of disclosure of operating segments was $69.03 \%$ with a minimum disclosure of $25.80 \%$ and a maximum of $87.09 \%$. The least disclosed information about transfer prices between segments, while the most widely disclosed is the type of segment product and service. From the calculation results of the Altman Z-Score the average sample company in the condition of financial difficulties is 0.90 . The area of distress according to the Altman Z-Score that is, $>2.99$ means healthy, 1.81-2.99 means it deteriorates in the future and $<1.81$ means high bankruptcy in the near future. The average Z-Score shows the sample company's serious financial problems that indicate bankruptcy in the near future. The average public ownership is $32.14 \%$ of the total outstanding shares, which means that $77.86 \%$ is owned by other types of shareholders, both institutional and managerial. As much as $28 \%$ of the sample companies were audited by BIG-4 audit firm , while the rest by Non BIG-4 audit firm. Descriptive data are presented in table 2 below:

Table 2 Descriptive Statistic

\begin{tabular}{lllll}
\hline Panel A & \multicolumn{5}{l}{} \\
\hline Contiuous Variabel & Minimum & Maximum & Mean & Std. Deviation \\
\hline SEGDISCL & 0.2580645 & 0.87096 & 0.690322 & 0.13403 \\
FDISS & 0.046999 & 2.71961 & 0.906077 & 0.60854 \\
LNSIZE & 2.3187 & 2.98378 & 27.38676 & 1.4199678 \\
DIFF & 0.1202810 & 0.93225 & 0.3214511 & 0.77934 \\
\hline Panel B & \multicolumn{5}{l}{} \\
\hline Dummy Variables & Frequency & Percentage & \\
AUD & 7 & $70 \%$ & \\
Non Big 4 & 3 & $30 \%$ & \\
Big 4 & 10 & $100 \%$ & \\
\hline Total & \multicolumn{5}{l}{} \\
\hline SEGDISCL is level of operating segment disclosure; FDISS is financial distress; LNSIZE is Logarithm \\
natural of total asset; DIFF is percentage of public ownership; AUD is audit quality with measurement 1 \\
for firm audited by Big-4 audit firm and 0 for others.
\end{tabular}


Are Financial Distress and Firm Characteristics Restrict The Operating Segment

Disclosure in Marine Industry?

\section{Analysis Method}

This study uses multiple linear regression analysis by classical assumption test. Classical assumption test consists of multicollinearity, heteroscedasticity, autocorrelation and normality.

Table 3 Multicollinearity Test

\begin{tabular}{ll}
\hline \multicolumn{1}{c}{ Variable } & \multicolumn{1}{c}{ VIF } \\
\hline DISS & 1,120 \\
SIZE & 2,205 \\
AUD & 2,205 \\
DIFF & 1,108 \\
\hline
\end{tabular}

\section{Multicollinearity test}

Multicollinearity test uses the value of Variance Inflation Factors (VIF). Multicollinearity exists if VIF> 10. Test results as shown in table 3. From the results of multicollinearity testing it can be seen that VIF of all variables is above 10, which means that there is no multicollinearity. From table 4 it can be seen that all of these variables do not have a strong correlation because the correlation is not greater than 0.8 . The correlation matrix in this study can be seen in table 4 .

\section{Table 4 Matrix of Correlation}

\begin{tabular}{lllll}
\hline \multicolumn{1}{c}{ Correlation } & DISS & SIZE & AUD & FISS \\
\hline FDISS & 1,000 & 0,165 & $-0,166$ & $-0,285$ \\
LNSIZE & 0,165 & 1,000 & $-0,738$ & $-0,062$ \\
AUD & $-0,166$ & $-0,738$ & 1,000 & 0,048 \\
FISS & $-0,285$ & $-0,062$ & 0,048 & 1,000
\end{tabular}

DISS: Financial Distress; LNSIZE: Logarithm natural of total asset; AUD: auditor quality; FISS: public ownership

\section{Heteroscedasticity Test}

To find heteroscedasticity in this study tested using the Glejser test. The problem of heteroskesdasitas occurs if the $\mathrm{p}$ value is $<0.05$. In testing conducted all variables have a $\mathrm{p}$ value $>0.05$, so there is no heteroscedicity on all variables. The results of the glejser test can be seen in table 5 below:

Table 5 Glejser Test

\begin{tabular}{ll}
\hline \multicolumn{1}{c}{ Variable } & \multicolumn{1}{c}{ Sig } \\
\hline DISS & 0,871 \\
SIZE & 0,672 \\
AUD & 0,500 \\
FISS & 0,70 \\
\hline
\end{tabular}

\section{Autocorrelation Test}

Autocorrelation test is used to determine whether the error in the regression model has a correlation between period errors with each other. In this study using Durbin Watson. If Durbin Watson is between -2 and 2, autocorrelation does not occur. The results of Durbin Watson's test showed that the value of Durbin Watson was 1.586, which meant that there was no autocorrelation problem.

\section{Normality Test}

The normality test is used to determine whether the variable is normally distributed. Kolmogorov Smirnov test was used in this study to test for normality. The result shows Sig 0.300>0.05, which means the data is normally distributed. 


\section{Discussion}

The regression test results obtained the coefficients of each variable as follows:

$$
\text { SEGDISCL }=0.017 \cdot \mathrm{X} 1+(-0.26) \cdot \mathrm{X} 2+(-0.478) \cdot \mathrm{X} 3+0 \cdot 46 \cdot \mathrm{X} 5+\varepsilon
$$

Regression test results are shown in table 6 . Hypothesis 1 proposed in this study is that financial distress has a significant effect on segment disclosure rates, the results show a coefficient of 0,46 and a significance of 0.097 significant at the level of $10 \%$. This means that financial distress has a positive effect on the level of segment disclosure. The smaller Z-score indicates the potential for higher financial difficulties. This means that the higher the z-score (the potential for the company to be healthier in finance), the higher the level of segment disclosure, and vice versa if the company experiences increasingly serious financial difficulties. Greater costs are needed for broader disclosures, making it difficult for companies that experience financial difficulties. If the company wants to convey information that is very helpful in the market, then there are delivery costs incurred, they are more willing to provide information on the overall performance of the company but are more reluctant to disclose segment specifications (Arya, Frimor, \& Mittendorf, 2010). In addition, the bad side of the company will be seen by competitors and investors, especially if the cause is a problematic segment.

Table 6 Result of Regression Test

\begin{tabular}{|c|c|c|}
\hline Variable & Coefficient & Significant \\
\hline FDISS & 0.46 & $0.097 *$ \\
\hline LNSIZE & 0.017 & 0.307 \\
\hline AUD & -0.26 & 0.616 \\
\hline DIFF & -0.478 & $0.000 * *$ \\
\hline R-Square & \multicolumn{2}{|c|}{0.379} \\
\hline Adj R-Square & \multicolumn{2}{|c|}{0.324} \\
\hline Prob (F-Statistic) & \multicolumn{2}{|c|}{0.000} \\
\hline $\begin{array}{l}\text { ** Signifikan pad } \\
\text { * Siginifikan pada }\end{array}$ & & \\
\hline
\end{tabular}

In table 6 hypothesis 2 test shows a coefficient of 0.017 and $p$ value of 0.307 which means that the size of the company does not significantly affect the level of disclosure of the segment. This means that hypothesis 2 cannot be supported. The size or size of the company's assets is not a consideration in segment disclosure, because even large companies will consider the usefulness of the information provided to stakeholders and their impact on the company even though it has sufficient funds to disclose.

Hypothesis 3 test produces a coefficient of -0.26 and $p$ value 0.616 as shown in table 7 . These results mean that the auditor's quality does not significantly affect the operating segment disclosure level and hypothesis 3 fails to be supported. There is no difference in disclosing segment information by companies audited by big-4 audit firm and non big-4 audit firm for marine companies listed on the IDX. The number of companies audited by the Big-4 audit firm and the average disclosure of the business sector in the field of business is quite high, which is above 50\% indicating that a lot of segment information is considered important to be delivered even though the company is not audited by big- 4 audit firm.

Furthermore, hypothesis 4 has been successfully supported with a coefficient of -0.478 and $p$ value of 0.000 (table 7 ) which means that public ownership has a significant effect on the level of segment disclosure. In this study the results show a negative direction, namely the higher the public ownership, the smaller the segment disclosure level. The concentration of ownership in the marine sector company is not on shares owned by the public or the public, but to the institution or management. When 


\section{Are Financial Distress and Firm Characteristics Restrict The Operating Segment Disclosure in Marine Industry?}

public ownership is small, institutional ownership is higher so that disclosure is more, because institutional shareholders will exercise more oversight than public shareholders.

The regression model test results obtained determinant coefficient value (Adj $\mathrm{R}$ Square) 0.324, which means Financial Distress, firm size, auditor quality and public ownership can explain $32.40 \%$ variation of the level of disclosure of operating segments. The F ANOVA test results show a significant value of 0,000 at level 5\% which means that the regression model is suitable to be used for the prediction model of operating segment disclosure level.

\section{Conclusions}

This study aims to examine the effect of financial distress, firm size, auditor quality, and public ownership on the level of disclosure of operating segments. The results of this study indicate $69 \%$ fulfillment of disclosure of segments by maritime sector companies. We find that financial distress has a positive effect on the extent of segment disclosure. This shows that in conditions of financial difficulties the company will provide less operating segment information. Many companies are reluctant to disclose segment information because of strategic and competitive hazards such as disclosing company strategy, level of overseas operations and internal integration to competitors that may be related to its disclosure (Odia \& Imagbe, 2015).

Public ownership has a negative influence on the extent of segment disclosure which means more public ownership, the more segment disclosure. These results support the research of Ahmad and Siregar (2013) but have different directions. This is due to the large institutional ownership of the company, so that the interests of institutional ownership are also considered. Variable company size, the quality of the auditor does not have a significant effect on the level of disclosure of the operating segment

The limitation of this study is the very limited number of samples and the segment index measurement that refers to IAS 14 with consideration of the research period carried out before and after the revision of PSAK which refers to IFRS 8 and the transition period of IFRS implementation. For further research can expand the sample and use measurements that refer to IFRS 8.

\section{References}

Alfaraih, M. M., \& Alanezi, F. S. (2011). What explains variation in Segment Reporting? Evidance From Kuwait. International Business \& Economics Research Journal, 10 (7).

Alzenil, F. S., Alfaraih, M. M., \& Alshammari, S. S. (2016). Operarting Segments (IFRS 8) required disclosure and the specific-characteristics of Kuwaiti Listed Companies. International Business Research, 9(1).

Arifin, M., Ruwanti, S., \& Kusasi, F. (2016). Pengaruh kinerja perusahaan bidang kelautan yang terdaftar di Bursa Efek Indonesia terhadap kualitas laba. Jurnal Ekonomi Maritim Indonesia , 7(1).

Arya, A., Frimor, H., \& Mittendorf, B. (2010). Discretionary disclosureof proprietaryinformation in a multisegment firm. Management Science, 56(4), 645658.

Berger, P. G., \& Hann, R. N. (2007). Segment of Profitability and Proprietary and agency cost of disclosure. The Accounting Review , 82(4).

Blanco, B., Lara, J. M., \& Tribó, J. (2014). The relation between segment disclosure and earnings quality. J. Account. Public Policy . 
Efferin, S., \& Rudiawarni, F. A. (2014). Memahami prilaku stakeholders Indonesia dalam adopsi IFRS: Tinjauan aspek kepentingan, bahasa dan budaya. Jurnal Akuntansi dan Keuangan Indonesia , 11(2), 138-164.

Harrison Jr, W. T., Horngren, C. T., Thomas, C. W., Tietz, W. M., \& Suwardy, T. (2017). Financial Accounting International Financial Reporting Standards. (Eleventh ed.). Pearson.

Hermalin, B. E., \& Weisbach, M. S. (2012). Information disclosure and corporate governance. The Journal of Finance , 67(1), 195-233.

Holder-Webb, L., \& Cohen, J. R. (2007). The association between disclosure, distress, and failure. Journal of Business Ethics , 75(3), 301-3014.

Ikatan Akuntansi Indonesia. (2015). Pernyataan Standar Akuntansi Keuangan Nomor 1: Penyajian Laporan Keuangan.

Ikatan Akuntansi Indonesia. (2014). Pernyataan Standar Akuntansi Keuangan Nomor 5: Segmen Operasi.

International Accounting Stadards Board. (2006). International Financial Reporting Standards No 8 Operating Segment.

Ibrahim, K. (2015). The impact of firm characteristics on IFRS 8 disclosure in the transation period in Nigeria. International Journal of Economic Sciences , 4(4).

Jensen, M. C., \& Meckling, W. H. (1976). Theory of the Firm: Managerial Behavior, Agency Cost and Ownership Structure. Journal of Financial Economics , 3(4), 305-360.

Jiao, Y. (2011). Corporate disclosure, market valuation and Firm Performance. Financial Management , 40(3), 647-676.

Juniarti. (2013). Good Corporate Governance and Predicting Financial Distress Using Logistic and Probit Regression Model. Jurnal Akuntansi dan Keuangan, 15(1), 4350 .

Kobbi-Fakhfakh, S., Shabou, R. M., \& Pigé, B. (20180. Determinants of segment reporting quality: evidence from EU. Journal of Financial Reporting and Accounting , 16(1), 84-107.

Kusumayani, N. L., \& Wirama, D. G. (2016). Good corporate governance sebagai pemoderasi pengaruh diversifikasi operasi dan diversifikasi geografis pada manajemen laba. E-Jurnal Akuntansi Universitas Udayana, 14(3).

Muhammad, F., \& Siregar, S. V. (2014). Pengungkapan Segmen Operasi: FaktorFaktor yang Mempengaruhi dan Dampaknya terhadap Biaya Modal Ekuitas. Ekuitas: Jurnal Ekonomi dan Keuangan , 18(3), 330-349.

Odia, J., \& Imagbe, V. (2015). Towards the Usefulness and Implications of Segment Reporting Standards. Mediterranean Journal of Social Sciences , 6(6), 30-40.

Salendrez, H. E. (2014). Operating segment disclosure practices of selected publicly listed companies in the Philippine manufacturing industry. Asia Pacific Business \& Economics Perspectives , 2(1), 78-89. 
Are Financial Distress and Firm Characteristics Restrict The Operating Segment

Disclosure in Marine Industry?

Schvirck, E., Lunkes, R. J., \& Gasparetto, V. (2013). Information disclosure per operating segment: A panorama of the application of CPC 22. Journal of Education and Research in Accounting , 7(2), 128-142.

Sucuahi, W. T. (2013). Firm size as predictor of compliance to international financial reporting standards (IFRS) 8. IAMURE International Journal of Business and Management , 6, 45-60.

Utami, K., \& Siregar, S. V. (2016). Analisis Pengaruh Pengungkapan Segmen Terhadap Kualitas Laba. Simposium Nasional Akuntansi XIX. Lampung.

Wardhani, R. (2007). Mekanisme Corporate Governance dalam perusahaan yang mengalami permasalahan keuangan. Jurnal Akuntansi dan Keuangan Indonesia , 14(1), 95-114.

Wijantini. (2006). Voluntary disclosure in annual reports of financially distressed company in Indonesia. Gadjah Mada International Journal of Business , 8(3), 343365 .

Yeo, H. (2016). Solvency and Liquidity in Shipping Companies. Asian Journal of Shipping and Logistics , 32(4), 235-241. 